\title{
SATISFACTION OF DRINKING WATER NEEDS IN VILLAGES OF STARA ZAGORA MUNICIPALITY
}

\author{
G. Sandeva*, P. Gidikova, R. Deliradeva \\ Department of Hygiene, Epidemiology and Infectious Diseases, Medical Faculty, Trakia University, \\ Stara Zagora, Bulgaria
}

\begin{abstract}
Supplying sufficient quantities of safe drinking water to citizens is one of the most important tasks of each country. According to national reports drinking water supplied to Bulgarian villages is not sufficiently controlled. PURPOSE: To determine whether the village residents of Stara Zagora municipality are satisfied with the quantity and quality of the supplied drinking water. METHODS: Households in 46 villages were interviewed for the study. RESULTS: The survey revealed that $87 \%$ of respondents believed they're getting enough water, but $63 \%$ were not satisfied with its quality. For $74 \%$ of the respondents water consumption corresponded to the national average $\left(2-4 \mathrm{~m}^{3}\right.$ per person per month). The main complaints concerning water quality were of unpleasant taste, smell of chlorine and high hardness. Due to the poor quality of drinking water $80 \%$ of respondents reported that they occasionally had to buy bottled water. A worrying fact was that $41 \%$ used tap water for watering their garden, thus wasting drinking water resources. CONCLUSIONS: The village residents in Stara Zagora municipality are partly satisfied with the quality of drinking water. It is necessary, however, to take significant measures to strengthen the quality control performed by water supply companies and supervisory authorities, especially in view of the increased cases of heavy rains and floods in the recent months.
\end{abstract}

Key words: drinking water, water consumption, rural areas

\section{INTRODUCTION}

Providing sufficient quantities of safe drinking water to citizens is one of the most important health policies of each country. The strict control performed regularly by water supply companies and the Regional health inspections should ensure continuous upholding of high quality standards for drinking water for all Bulgarian citizens. Unfortunately, according to national reports from recent years the residents of villages and small towns in Bulgaria receive drinking water of lesser quality more often compared with large city dwellers, the main causes being outdated water network, inaccurate manual disinfection and lack of investments and sustainable development in the sector (1).

Current quality requirements for drinking water are recorded in Ordinance No 9/2001 and include permissible levels for organoleptic, chemical, microbiological, and radiological

\footnotetext{
*Correspondence to: Gergana Sandeva, 11 Armeyska Str, 6000 Stara Zagora, Bulgaria, Phone: +35942664240, E-mail: geri_sandeva@yahoo.com
}

indicators (2). Some of these indicators (levels of nitrous compounds, heavy metals, hydrocarbons, pesticides, some types of bacteria) are directly linked to increased health risk for consumers.

In most cases people cannot sense increased levels of water contaminants. Consumers' estimation of water quality is mostly influenced by its organoleptic properties (i.e. smell, taste, color, residue), and less by factors like risk perception, attitudes towards water chemicals, familiarity with specific water properties, trust in suppliers, past problems attributed to water quality and information provided by the mass media and interpersonal sources (3).

It has been proposed that drinking water consumers should be considered as sentinels who monitor water quality (4), therefore it is important to regularly survey their attitudes towards supplied drinking water.

The PURPOSE of this study was to determine whether the village residents of Stara Zagora 
municipality are satisfied with the quantity and quality of the supplied drinking water.

\section{MATERIALS AND METHODS}

Households from 46 villages in Stara Zagora municipality were interviewed in October 2014. All surveyed villages received groundwater via piping systems after disinfection with chlorine. All interviewed villagers had water meters installed in their
SANDEVA G.

houses. No sewerage systems for wastewater were present in any of the villages, so wastewater for each house was collected in individual septic tanks. Because of the lack of sewage systems all surveyed households used pit latrines.

For the survey we used the Water Supply Questionnaire For Citizens with 18 topics proposed by Samwel et al. (5) shown on Table 1.

Table 1. Water supply questionnaire for citizens.

\begin{tabular}{|l|l|}
\hline $\mathbf{1}$ & Do you have centralized water connection in the house? \\
\hline $\mathbf{2}$ & Which other water sources do you use? \\
\hline $\mathbf{3}$ & With which water do you irrigate the garden? \\
\hline $\mathbf{4}$ & How much water do you need per month for your household? \\
\hline $\mathbf{5}$ & Is there enough water available? \\
\hline $\mathbf{6}$ & Do you think the drinking water quality is good? \\
\hline $\mathbf{6 a}$ & If not, please explain. \\
\hline $\mathbf{6 b}$ & If the water quality is not good, what is the reason? \\
\hline $\mathbf{7}$ & Do you treat/boil water for drinking? \\
\hline $\mathbf{8}$ & Do you think you get ill from the drinking water? \\
\hline $\mathbf{9}$ & Do you use bottled water? \\
\hline $\mathbf{1 0}$ & How much do you pay monthly for bottled water? \\
\hline $\mathbf{1 1}$ & Do you have a water meter? \\
\hline $\mathbf{1 2}$ & How much do you pay monthly for the public water supply? \\
\hline $\mathbf{1 3}$ & Do you have copper, lead, or another type of piping in your house? \\
\hline $\mathbf{1 4}$ & Do you have complaints on the drinking water supply's quality? \\
\hline $\mathbf{1 5}$ & What kind of toilet do you have - flush toilet or pit latrine? \\
\hline $\mathbf{1 6}$ & Is wastewater of your house/toilet treated? \\
\hline $\mathbf{1 7}$ & What are your wishes concerning the drinking water supply? \\
\hline & \\
\hline
\end{tabular}

All collected data were processed and analyzed using Microsoft Excel 2007.

\section{RESULTS}

For most of the respondents (74\%) water consumption was in the range of 2-4 $\mathrm{m}^{3}$ per person per month (Figure 1) and only $17 \%$ of the households used more than $4 \mathrm{~m}^{3}$ per person per month.

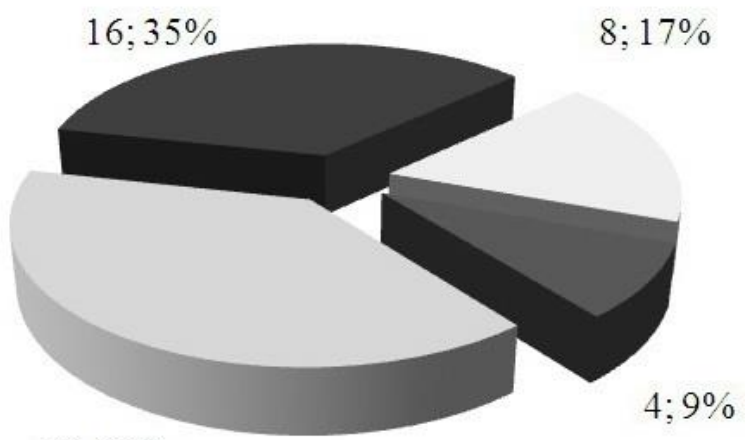

$18 ; 39 \%$

$$
\square<2 \quad 2-3 \quad \square 3-4 \quad>4
$$

Figure 1. Water use per person per month in a household (in $\mathrm{m}^{3}$ ).

Water consumption was closely linked to the monthly cost of drinking water for each household. For $37 \%$ of the respondents this cost was between 10-19 BGN, for 28\% between 20-29 BGN, and for 26\% - less than $10 \mathrm{BGN}$ per month.
Concerning the amount and quality of supplied drinking water the survey revealed that $87 \%$ of respondents believed they're getting enough water, but $63 \%$ were not satisfied with its quality (Figure 2). 


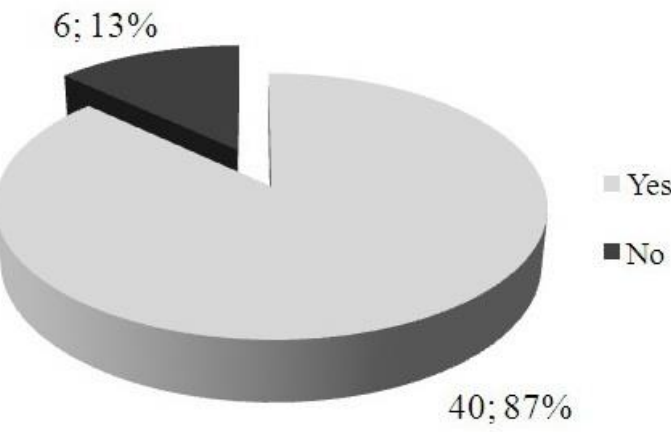

Quantity

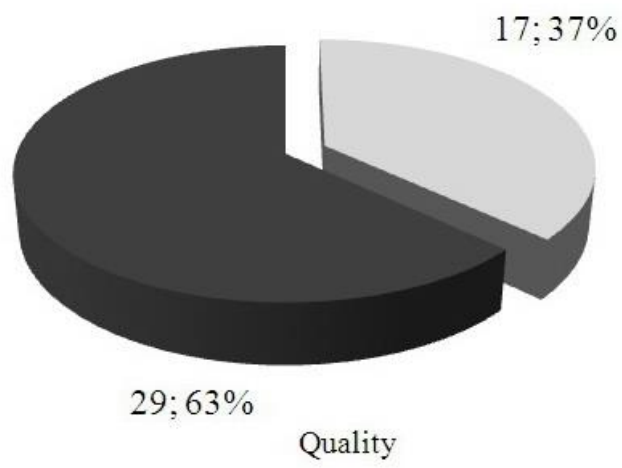

Figure 2. Satisfaction with water supply.

$52 \%$ of the villagers had some complaints with the supplied drinking water. The main complaints on water quality, presented on Figure 3, were of unpleasant earthy taste (in 9 cases, 19\%) and earthy smell (6 cases, 13\%), smell of chlorine (13 cases, 27\%), and high hardness (15 cases, 31\%). Less encountered complaints were unnaturally colored water (usually brown) and the presence of residue.

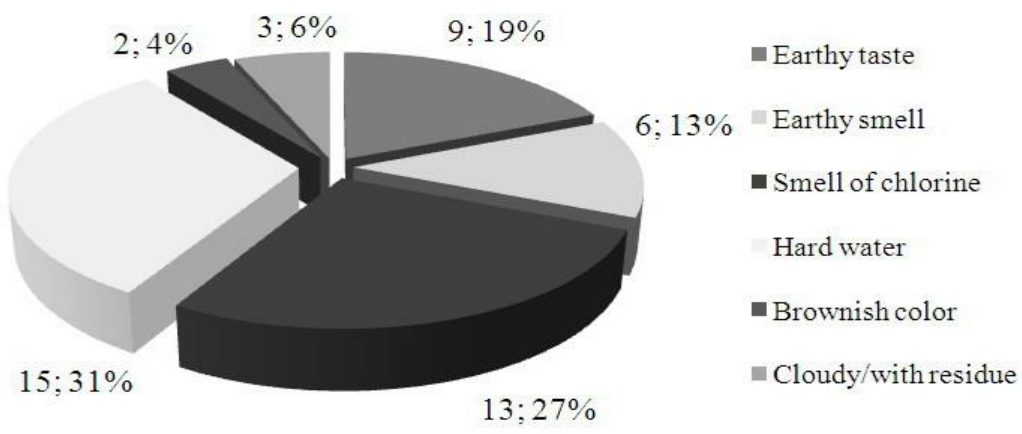

Figure 3. Complaints with drinking water quality.

None of the surveyed villagers admitted they treated tap water in any way to make it safer (by boiling or filtering it), but $80 \%$ of respondents reported they occasionally had to buy bottled water due to poor drinking water quality. Furthermore, although over $60 \%$ of the respondents complained about the drinking water quality, only $7 \%$ expressed a worry that supplied tap water might make them sick.

Another question linked to drinking water safety was the presence in the household of lead or copper pipes. None of the surveyed villagers had those types of piping in their houses.

Around $45 \%$ of respondents admitted using tap water for watering their garden, alone $(4 \%)$ or in combination with pumped groundwater (41\%). $48 \%$ used only water pumps for irrigation, and $7 \%$ - a combination of groundwater and water from an irrigation canal present in the village.

$26 \%$ of the respondents expressed wishes regarding the supplied drinking water (Figure 4). The main issues were with quality $(41 \%)$ and price $(35 \%)$.

$$
2 ; 12 \%
$$

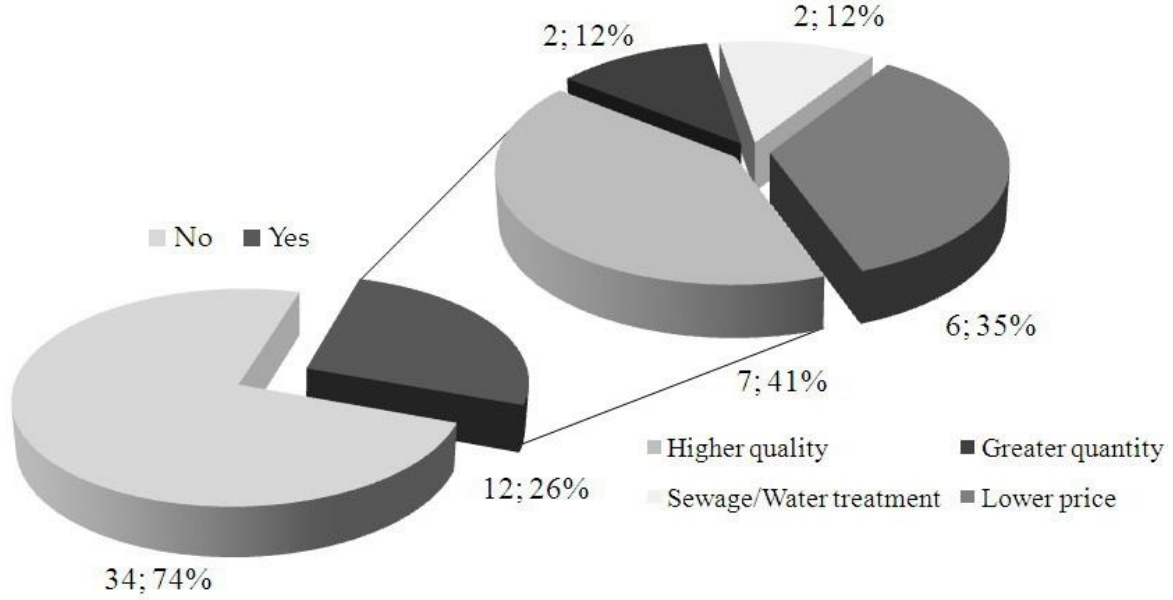

Figure 4. Wishes concerning the drinking water supply. 
Some people wished for enough water to be supplied (2 cases, 12\%) and for sewage and water treatment plant to be installed (also 2 cases).

\section{DISCUSSION}

Current norms for the amount of supplied water are the same for all residential buildings, regardless of the size of the settlement (6). For most of the surveyed villagers water consumption corresponded to the national average of 2-4 $\mathrm{m}^{3}$ per person per month, despite national estimates stating that village residents use less tap water compared with city dwellers (1). This result could partly be due to some village residents using tap water in their gardens - a practice that significantly increases water consumption. Using tap water for garden irrigation leads to wasting drinking water resources and although frowned upon, it is still not explicitly forbidden by the government or the local authorities.

National regulation states that organoleptic qualities of drinking water should be acceptable to consumers and without significant fluctuations compared to the usual state (2). But if consumers detect unusual flavor and smell in their drinking water, they are likely to believe that it probably is not safe (7). Earthy smell and taste of drinking water is a common problem and is usually attributed to the presence of geosmin - an organic compound produced by actinobacteria and released in water when these microorganisms die (8). Geosmin is detected by the human olfactory system in extremely small concentrations - as low as $0,005 \mathrm{ng} / \mathrm{L}$ (9) and is typical of surface water sources. Groundwater can be contaminated with geosmin during heavy rainfall and floods. The usual methods used for purification and disinfection of drinking water in Bulgaria do not remove organoleptic flaws caused by geosmin. Usually there is no correlation between organoleptic properties of drinking water contaminants and their toxicity (10). Still, water supply companies should adopt a water quality goal that allows them to not only meet the minimums of the regulations, but also meet the customer's high standards concerning the taste and smell of water (7).

Hard water was another commonly reported water quality problem in the survey. Hard water is usually defined as water which contains high concentrations of calcium and magnesium ions, but also aluminum, barium, strontium, iron, and zinc carbonates and hydrocarbonates. Numerous studies suggest the protective effect of hard water in relation to cardiovascular diseases, diabetes, gastrointestinal cancer, osteoporosis and other diseases (11). Despite its health advantages, hard water is generally considered a problem by consumers because of its negative impact on domestic duties like cooking and washing clothes (12).

Many respondents had an issue with the smell of chlorine in water, usually detected when excessive levels of free chlorine are present. Excessive levels of chlorine in water are caused by the still widely spread unautomated application of disinfectants in rural areas that often cannot supply precise chlorine doses (1). Chlorine and other water disinfectants can lead to formation of disinfection by-products through a reaction with naturally occurring organic matter, anthropogenic contaminants, bromide, and iodide. More than 600 disinfection by-products have been identified, but only a small portion of them have undergone toxicological studies. The possible health effects of interactions between different disinfection by-products have also not been evaluated (13). Current scientific opinion is that some of these compounds have genotoxic and carcinogenic properties. To protect consumers' health it is imperative to ensure quality disinfection of drinking water without exceeding the regulation limits of used disinfectants (for chlorine $-0,3-0,4 \mathrm{mg} / \mathrm{L}$ ). The best way to reach this goal is to install automated disinfection facilities.

Water piping materials can have various health effects. Niquette et al. tested antibacterial qualities of different piping materials and found that densities of bacterial biomass fixed on plastic-based materials (polyethylene and polyvinylchloride) were the lowest. Densities of bacterial biomass fixed on gray iron were 10 to 45 times higher than those measured on plastic-based materials and cement-based materials had intermediate values (14). Another problematic compound in water pipes is lead. Lead can react with free chlorine in water to produce a red-brown colored solid. It can also leach from brass piping when exposed to chloramines, other commonly used water disinfectants (15). Copper, on the other hand, has antibacterial and antiviral properties (16), but copper piping is not widely spread in Bulgaria.

Despite having complaints about water quality, only a small percentage of respondents believed they might get ill from the supplied drinking water. These attitudes are consistent with current survey research indicating that most people in countries with reliable supplies 
perceive tap water risks as small (3). Therefore the fact that most of the surveyed villagers regularly bought bottled water could be attributed not to worries of contaminated tap water, but to poor organoleptic qualities of supplied drinking water.

\section{CONCLUSIONS}

The survey on satisfaction of drinking water needs in villages from Stara Zagora municipality lead to the following conclusions:

- Monthly water consumption per capita in rural areas around Stara Zagora was the same as the national average.

- The majority of the surveyed village residents were not satisfied with the quality of drinking water.

- Most commonly reported problems regarding drinking water quality were related to organoleptic characteristics and high hardness.

- Despite its high price, $80 \%$ of respondents occasionally used bottled water.

- In rural areas many people still used drinking water for watering gardens.

It is necessary to strengthen quality control of drinking water in rural areas performed by water supply companies, control authorities (Regional Health Inspections) and local authorities, especially in view of the frequent heavy rains and floods which increase the risk of contamination of water sources.

\section{ACKNOWLEDGEMENTS}

This study was conducted as part of Project 23/2013 "A study of indicators for drinking water disinfection in villages of Stara Zagora Municipality" of Trakia University, Stara Zagora. The authors would like to thank the University for its support and the opportunity to participate in the Project.

\section{REFERENCES}

1. Bulgarian Executive Environment Agency, National report on the status and conservation of environment in Bulgaria in 2012. Ministry of Environment and Water of Bulgaria, Sofia, Bulgaria, 2014.

2. Bulgarian Parliament, Ordinance No 9 on the quality of water intended for drinking purposes. State Gazette No30 of 28.03.2001, Sofia, Bulgaria, 2001.

3. De França Doria, M., Factors influencing public perception of drinking water quality. Water Policy, 12(1):1-19, 2010.

4. Dietrich, A.M., Aesthetic issues for drinking water. Journal of Water and Health, 4:11-16, 2006.

5. Samwel, M., Klimek, F., Wendland, C., Iskreva, D., Mihaylova, B. and Yordanova,
A., Water Safety Plan Compendium - Local Action for Safe Water, WECF e.V., Anita Roetzer, Germany, 2012.

6. Bulgarian Parliament, Ordinance No 4 on the design, construction and operation of water supply and sewage systems in buildings. State Gazette No53 of 28.06.2005, Sofia, Bulgaria, 2005.

7. McGuire, M.J., Off-flavor as the consumer's measure of drinking water safety. Water Science and Technology, 31(11): 1-8, 1995.

8. Gerber, N.N. and Lechevalier, H.A., Geosmin, an earthy-smelling substance isolated from Actinomycetes. Applied Microbiology, 13(6):935-938, 1965.

9. Polak, E.H. and J. Provasi, J., Odor sensitivity to geosmin enantiomers. Chemical Senses, 17(1):23-26, 1992.

10. Young, W.F., Horth, H., Crane, R., Ogden, T. and Arnott, M., Taste and odour threshold concentrations of potential potable water contaminants. Water Research, 30(2):331-340, 1996.

11. Sengupta, P., Potential health impacts of hard water. International Journal of Preventive Medicine, 4(8):866-875, 2013.

12. Abeliotis, K., Candan, C., Amberg, C., Ferri, A., Osset, M., Owens, J. and Stamminger, R., Impact of water hardness on consumers' perception of laundry washing result in five European countries. International Journal of Consumer Studies, 39(1):60-66, 2015.

13.Richardson, S.D., Plewa, M.J., Wagner, E.D., Schoeny, R. and DeMarini, D.M., Occurrence, genotoxicity, and carcinogenicity of regulated and emerging disinfection by-products in drinking water: A review and roadmap for research. Mutation Research/Reviews in Mutation Research, 636(1-3): 178-242, 2007.

14.Niquette, P., Servais, P. and Savoir, R., Impacts of pipe materials on densities of fixed bacterial biomass in a drinking water distribution system. Water Research, 34(6):1952-1956, 2000.

15.Edwards, M. and Dudi, A., Role of chlorine and chloramine in corrosion of lead-bearing plumbing materials. Journal (American Water Works Association), 96(10): 69-81, 2004.

16.Lehtola, M.J., Miettinen, I.T., Keinänen, M.M., Kekki, T.K., Laine, O., Hirvonen, A., Vartiainen, T. and Martikainen, P.J., Microbiology, chemistry and biofilm development in a pilot drinking water distribution system with copper and plastic pipes. Water Research, 38(17):3769-3779, 2004. 
Trakia Journal of Sciences, Vol. 13, Suppl. 2, 2015 